\title{
High-resolution climate evolution derived from the sediment records of Erlongwan Maar Lake since 14 ka BP
}

\author{
YOU HaiTao ${ }^{1} \&$ LIU JiaQi ${ }^{2 *}$ \\ ${ }^{1}$ Key Laboratory of Computational Geodynamics of Chinese Academy of Sciences; College of Earth Science, Graduate University of the Chinese \\ Academy of Sciences, Beijing 100049, China; \\ ${ }^{2}$ Institute of Geology and Geophysics, Chinese Academy of Sciences, Beijing 100029, China
}

Received February 24, 2012; accepted April 23, 2012; published online May 30, 2012

\begin{abstract}
Varve counts with AMS ${ }^{14} \mathrm{C},{ }^{137} \mathrm{Cs}$ and ${ }^{210} \mathrm{~Pb}$ dating of sediments $(0-900 \mathrm{~cm})$ from Erlongwan Maar Lake, NE China were used to establish a high-resolution chronology series for the late Quaternary. Dry density, total organic carbon (TOC) content, total nitrogen $(\mathrm{TN})$ content, TOC/TN ratios and stable organic carbon isotope $\left(\delta^{13} \mathrm{C}_{\mathrm{org}}\right)$ ratios were continuously analyzed on this sediment profile. On the basis of lithological characters, sporo-pollen assemblages and geochemical analyses, we identified 6 climate stages within the last $14 \mathrm{ka}$ BP. The time before the Holocene (14-11.4 ka BP) represents a higher-order oscillation climatic transitional period (I). The entire Holocene climate development (from $11.4 \mathrm{ka}$ BP to present) exhibited an increasing temperature trend, although there were cold and warm alternations (II-VI). The periods included were: II (11.4-9.05 ka BP) warm-wet stage, III (9.05-7.4 ka BP) cold and warm fluctuation stage, IV (7.4-4.2 ka BP) smoothly warming climate stage, V (4.2-1.67 ka BP) climate optimum stage, and VI (from $1.67 \mathrm{ka}$ BP to present) cool and drier stage. Each climate stage began with a warming event and ended with an abrupt cooling event. This climate change cycle had unequal time spaces that were progressively shorter over time. Several abrupt climate shifts occurred at about 9.4-9.05, 8.5-8.2, 7.8-7.4, 4.6-4.2, 3.7-3.25, 2-1.67 and 0.3-0.03 ka BP. Thus, it can be seen that the climate has been warming since $1920 \mathrm{AD}$, which indicates a new climate stage.
\end{abstract}

Erlongwan, Maar Lake sediments, varve, climate variability

Citation: You H T, Liu J Q. High-resolution climate evolution derived from the sediment records of Erlongwan Maar Lake since 14 ka BP. Chin Sci Bull, 2012, 57: 3610-3616, doi: 10.1007/s11434-012-5244-6

The regularity and tendencies of climate change are hot debated issues. Deciphering climate change mechanisms from the last glacial maximum (LGM) to the latest $20 \mathrm{ka} \mathrm{BP}$ is a principal task in the science of global climate change [1]. In recent years, numerous studies focusing on the LGM have been conducted such as the analysis of high-resolution stalagmite records [2,3], and the modeling of palaeoclimate and associated driving mechanisms [4-11]. Numerous studies have also been published on lacustrine sediments and peat sequences [12-24]. For example, dust flux rates and paleohydrological conditions on a decadal scale over the past 220 years from the sediment record of Lake Sihailongwan [13]. The detailed paleomagnetic study on long

*Corresponding author (email: liujq@ mail.iggcas.ac.cn) sediment cores from Erlongwan Maar Lake, provided an important contribution to the ongoing database of a paleosecular variation master curve for East Asia [14]. Based on the response of carbon isotope fractionation of $\mathrm{C}_{3}$ plants in peat from Jinchuan [16] and the variation of $\delta^{13} \mathrm{C}_{\mathrm{org}}$ in the sediments from Xiaolongwan Maar Lake [15] to the variation in relative humidity or precipitation, the authors interpreted organic carbon isotopic composition as an indicator of humidity or precipitation. The study of the Hani peat sequence in the Changbai Mountain, NE China, also showed that the effective precipitation in NE China was variable during the early Holocene, probably due to short-term enhancement of summer monsoon rainfall at that time [18]. And that the Holocene Climatic Optimum was a period of warmer climate with lower effective precipitation, which 
contradicts evidence of wetter climates in most of East Asia $[19,20]$. The pollen data presented from the annually laminated sedimentary sequence of Sihailongwan Lake indicate that it was cold and dry between 16.7 and $14.45 \mathrm{ka}$ BP. Two short-term climatic reversals to colder and/or drier conditions were also recorded in the proxy data between 13.9 and $13.8 \mathrm{cal} \mathrm{ka} \mathrm{BP}$ and 13.1 and 12.9 cal ka BP. These correlated with the Oldest Dryas/Greenland Interstadial (GI) 1d event and the Gerzensee/Killarney/GI-1b oscillation, respectively [21]. The combination of geochemical and isotopic proxy parameters provides evidence for a division of climate development into four stages between 16.5 and $9.5 \mathrm{ka}$ BP. These include a cold and dry stage before $14.2 \mathrm{ka} \mathrm{BP}$, a warm optimum stage from 14.25-12.45 ka BP, a colder and drier stage from 12.45 to $11.6 \mathrm{ka} \mathrm{BP}$, and a stage of climatic amelioration with high variability in TOC and TN contents after $11.6 \mathrm{ka}$ BP [22]. In addition, three stages can be delineated during the past $18.5 \mathrm{ka} \mathrm{BP:} \mathrm{(1)} \mathrm{the} \mathrm{late} \mathrm{stage} \mathrm{of} \mathrm{the}$ Last Glacial (18.5-14.7 ka BP), (2) the last deglaciation (14.7-11.7 ka BP) and (3) the Holocene (11.7 ka BP-present). From this information, it can be concluded that change in atmospheric $\mathrm{CO}_{2}$ concentration is the controlling factor on variation of $\delta^{13} \mathrm{C}_{\text {org }}$ values in the Lake Sihailongwan area [23]. In this paper, we present a high-resolution chronology based on the precise varve counting from Erlongwan Maar Lake, then using a multi-proxy record, reconstruct climate evolution during the last $14 \mathrm{ka} \mathrm{BP}$ in this region.

\section{Study site and sediment sampling}

Erlongwan Maar Lake $\left(42^{\circ} 18.1^{\prime} \mathrm{N}, 126^{\circ} 21.4^{\prime} \mathrm{E}\right.$; Figure 1$)$ is situated in the Long Gang Volcanic Field (LGVF) in the Jilin Province, NE China [25]. The site is located at $722 \mathrm{~m}$ a.s.l. with an elliptical crater of $750 \mathrm{~m}$ from north to south and $500 \mathrm{~m}$ from east to west. Maximum water depth in the lake is $33 \mathrm{~m}$ (measured in 2009), and the lake surface covers an area of $0.3 \mathrm{~km}^{2}$. It is a water-filled volcanic crater of explosive origin that formed in the mid-late Early Pleistocene, and is surrounded by basalts, basaltic volcanic pyroclastic rocks and cinder.

The modern climate of the study region is controlled by the East Asia monsoonal system, which is associated with climatic features of the temperate continental monsoon climate. The mean annual precipitation is $775 \mathrm{~mm}$, concentrated in summer, and the mean annual temperature is 2 to $-4^{\circ} \mathrm{C}$. The vegetation is dominated by a coniferous and broad leaf forests.

During a joint drilling field trip with the Institute of Geology and Geophysics (IGG), Chinese Academy of Sciences, and the GeoForschungsZentrum (GFZ) Potsdam (Germany) in 2001, two long undisturbed-continuous sediment cores were recovered from Erlongwan Maar Lake. The two parallel cores were used to obtain one composite profile with a length of $2391 \mathrm{~cm}$ [14]. Sediment samples for dry density (at intervals of $1 \mathrm{~cm}$ ), geochemical analyses (at intervals of $4 \mathrm{~cm})$ and thin sections $(120 \mathrm{~mm} \times 35 \mathrm{~mm})$ were taken from the composite profile $0-900 \mathrm{~cm}$. All sampling and analyses were carried out in the laboratories of GFZ-Potsdam and IGG-CAS.

\section{Dating}

The chronology for the studied profile was established through varve counting [26], AMS ${ }^{14} \mathrm{C}$ radiocarbon dating, and ${ }^{137} \mathrm{Cs}$ and ${ }^{210} \mathrm{~Pb}$ dating [27]. A total of 125 petrographic thin sections were used to identify varve types and varve counts based on observations using stereoscopic and polarizing microscopes. Results indicate that there were two

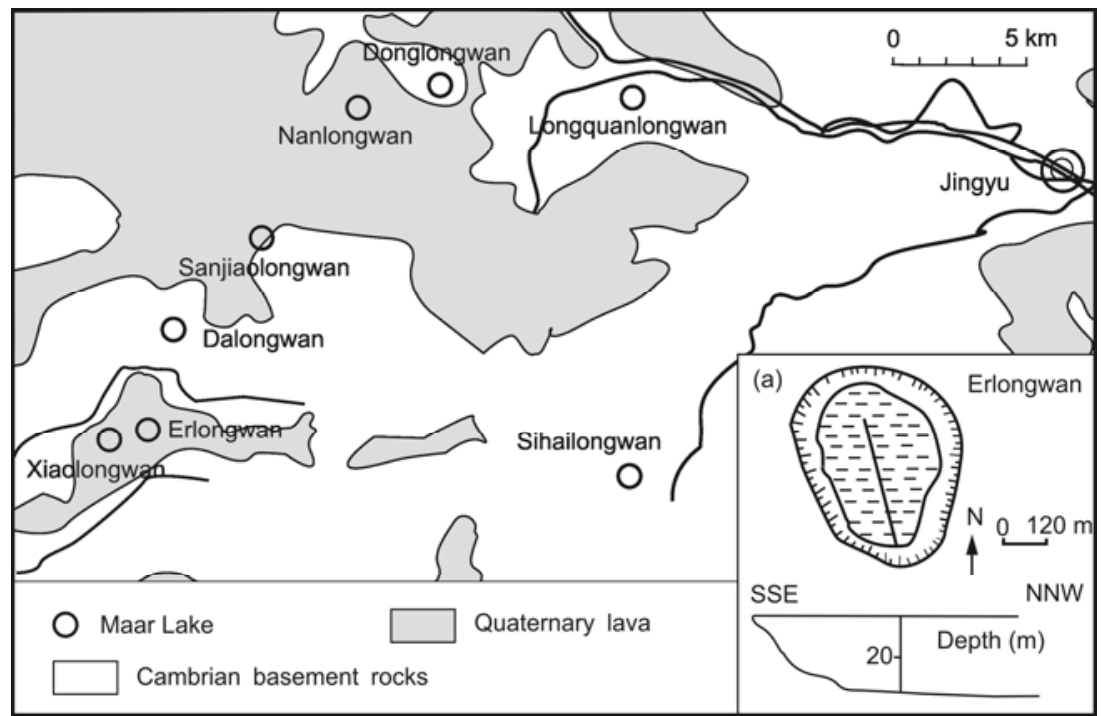

Figure 1 Location of Erlongwan Maar Lake and the shape of the lake basin (a) [25]. 
main varve types between $0-900 \mathrm{~cm}$ : biogenic varves and clastic varves [25], with annual biogenic and sedimentary characteristics suitable for varve counting. The varve counting age was 13989 a BP at $900 \mathrm{~cm}$ of the composite profile, with an error of $2 \%$ to $5 \%$. All sample ages referred to in the text represent corrected varve years BP. Missing varves and varves that were not identifiable led to counting errors in the profile. Thus, radioactive isotope dating methods also were used [27]. ${ }^{137} \mathrm{Cs}$ and ${ }^{210} \mathrm{~Pb}$ ages were obtained from the uppermost sediment interval of $0-5.5 \mathrm{~cm}$ at the IGG-CAS laboratory [27]. A total of 12 samples were collected from the fine laminated sediment core section for $\mathrm{AMS}^{14} \mathrm{C}$ dating. Two leaves were dated at the Radiocarbon Laboratory of Peking University, and the other ten bulk sediment samples were analyzed at the Poznan Radiocarbon Laboratory. All the ${ }^{14} \mathrm{C}$ ages were calibrated with the calibration program CALIB6.0 (http://calib.qub.ac.uk/calib/) (Table 1).
From Table 1, it is readily seen that ages between AMS ${ }^{14} \mathrm{C}$ dating and varve counts are in good agreement (correlation coefficient of 0.9988) (Figure 2), except for those at the lower part of the AMS ${ }^{14} \mathrm{C}$ dating age 16254-16901 a and varve age 13492 a $\mathrm{BP}$, which are quite different to the rest. This indicates that the two dating methods have a high level of confidence. Thus, the data show that with radioactive isotope absolute dating [14], varve counts can be a precise and effective dating method. Figure 3 is the corresponding relation between depth and varve age from the sediment composite profile.

The bottom of $796.9 \mathrm{~cm}$ (sample number at Poz-11747) has an AMS ${ }^{14} \mathrm{C}$ date that may have been affected by the impact of the "old carbon effect" caused by sampling a portion of the sedimentary section with abundant detritus, perhaps mixed with old carbonaceous material. Because this age cannot be determined as reliable, we have not considered

Table 1 Dating of $\mathrm{AMS}^{14} \mathrm{C}$ and varve counts $(0-900 \mathrm{~cm})$

\begin{tabular}{cclcc}
\hline Sample number & Depth of composite profile $(\mathrm{cm})$ & \multicolumn{1}{c}{ Dating sample } & AMS $^{14}$ age (cal a BP) $(2 \sigma)$ & Varve age $(\mathrm{a}$ BP) \\
\hline Poz-11744 & 44.5 & bulk sediment $^{\text {a }}$ & $515-635$ & 654 \\
B2-O 31.5 & 215.5 & leaf $^{\text {b) }}$ & $1406-1573$ & 1451 \\
Poz-20145 & 224.5 & bulk sediment $^{\text {a) }}$ & $1992-2155$ & 1749 \\
B2-O 63 & 247 & leaf $^{\text {b) }}$ & $2347-2543$ & 2208 \\
Poz-10988 & 256.7 & bulk sediment $^{\text {a) }}$ & $2917-3076$ & 2526 \\
Poz-20081 & 336 & bulk sediment $^{\text {a) }}$ & $5476-5645$ & 5287 \\
Poz-11746 & 412.3 & bulk sediment $^{\text {a) }}$ & $6994-7182$ & 6811 \\
Poz-11004 & 503.8 & bulk sediment $^{\text {a) }}$ & $8433-8600$ & 8368 \\
Poz-11743 & 624.95 & bulk sediment $^{\text {a) }}$ & $10784-11198$ & 10795 \\
Poz-20080 & 698.2 & bulk sediment $^{\text {a) }}$ & $12404-12623$ & 12086 \\
Poz-20144 & 743.5 & bulk sediment $^{\text {a) }}$ & $12868-13262$ & 12946 \\
Poz-11747 & 796.9 & bulk sediment $^{\text {a) }}$ & $16254-16901$ & 13492 \\
\hline
\end{tabular}

a) Analyzed at the Poznan Radiocarbon Laboratory; b) dated at the Radiocarbon Laboratory of Peking University.

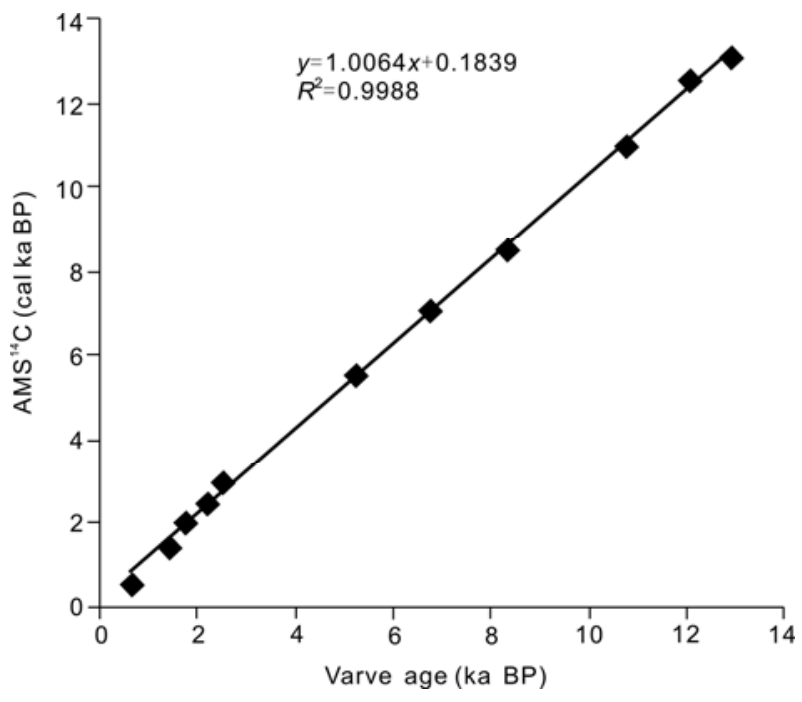

Figure 2 Comparison between the two dating methods.

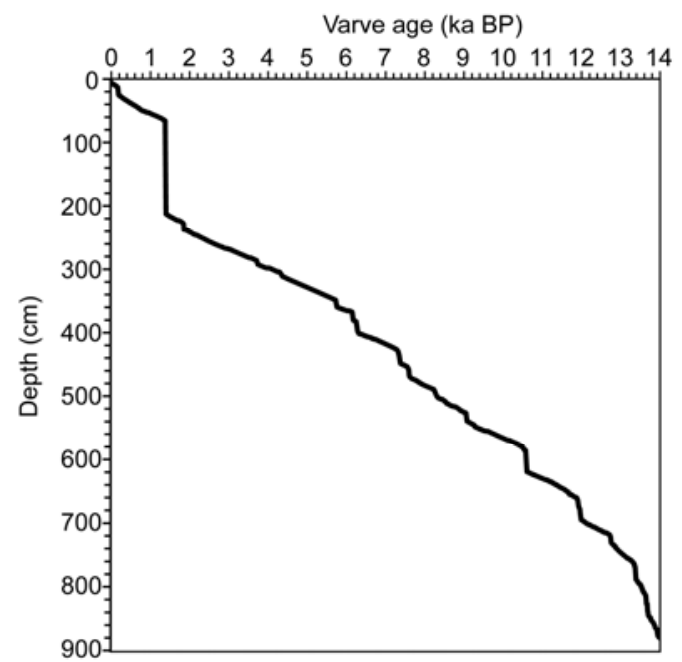

Figure 3 Relationship between core depth and varve age from the Erlongwan sediment composite profile. 
it in the establishment of the time series for this study.

\section{Significance of climatic proxy indexes}

Investigation on the evolution of the climate and environment during the past $14 \mathrm{ka} \mathrm{BP}$ was based on the dry density and geochemical analyses of 141 sediment samples from Erlongwan (Figure 4). It has been established that the dry density directly reflects climate change [28,29]. Generally, dry density decreases in lake sediments, indicating an increase in organic matter content. However, there is a decrease in terrigenous classic material, which results in sediments being loose and porous. As a result, low dry density reflects equable climatic conditions, and high values reflect deteriorating climate [23].

TOC content in lacustrine sediments comes primarily from land plants and aquatic organisms, depending on input quantity of organic matter, which is an essential parameter for reflecting organic matter contents in lakes. Variations in TOC and TN contents reflect the productivity [30] of the lake and climatic fluctuations [31,32]. Previous research has shown that TOC/TN ratios of lake sediments can be used to diagnose the relative percentage of organic matter contributed by aquatic organisms and land plants in lake sediments. Normally, the TOC/TN ratio of aquatic organisms is less than 10 because they containing more protein compared to land plants, which are more than 20 [31-35]. TOC/TN values with a mean of 11.3 revealed mixed contributions of endogenous and exogenous, but mainly endogenous aquatic organisms during the last $14 \mathrm{ka} \mathrm{BP}$. TOC content values reflect productivity in the lake, followed by temperatures. This is because productivity is controlled by nutrient conditions of the lake water and temperature [36,37].

Values of $\delta^{13} \mathrm{C}_{\text {org }}$ mainly are determined by organic matter source, and are affected by climate and environmental factors [38]. According to the TOC/TN ratios, organic matter in the Erlongwan sediment samples was derived from both land plants and aquatic organisms. Terrestrial plants were divided into $\mathrm{C}_{3}, \mathrm{C}_{4}$ and $\mathrm{CAM}$ types, according to the types of photosynthesis and different carbon atomicity. However, terrestrial plants were mainly $\mathrm{C}_{3}$ and $\mathrm{C}_{4}$ plants. This division is based on the fact that there were no CAM plants in this arid region [23]. In general, $\mathrm{C}_{3}$ land plants have lighter carbon isotope compositions and $\delta^{13} \mathrm{C}$ values ranging between $-35 \%$ and $-21 \%$. Meanwhile, $\mathrm{C}_{4}$ land plants are associated with heavier carbon isotope compositions with $\delta^{13} \mathrm{C}$ values ranging between $-20 \%$ and $-9 \%$ [39]. In addition, aquatic organisms include submerged plants, emergent plants and phytoplankton. In general, $\delta^{13} \mathrm{C}_{\mathrm{org}}$ values are between $-30 \%$ and $-24 \%$ o for emergent plants because their photosynthetic process uses atmospheric $\mathrm{CO}_{2}$. In normal circumstances, $\delta^{13} \mathrm{C}$ values of the $\mathrm{HCO}_{3}^{-}$in water are higher than those of atmospheric $\mathrm{CO}_{2}$ dissolved in lake waters. Thus, submerged plants, which absorb $\mathrm{CO}_{2}$ released from bicarbonate in water rather than atmospheric $\mathrm{CO}_{2}$, have relatively higher $\delta^{13} \mathrm{C}$ values between $-20 \%$ and $-12 \%$. With regard to plankton, if they mainly absorb atmospheric $\mathrm{CO}_{2}$ dissolved in the lake, their $\delta^{13} \mathrm{C}$ values would be similar to those of the $\mathrm{C}_{3}$ land plants. Conversely, if soluble atmospheric $\mathrm{CO}_{2}$ were depleted, plankton would absorb $\mathrm{CO}_{2}$ from bicarbonate in the lake water, and their $\delta^{13} \mathrm{C}$ values would be higher [23,33].

Our research results show that $\delta^{13} \mathrm{C}_{\text {org }}$ values in Erlongwan sediment samples were between $-30.33 \%$ and $-25.24 \%$, within the distribution range of land $\mathrm{C}_{3}$ plants, emergent plants and phytoplankton. However, there were hardly any emergent plants growing in the LGVF [40]. Thus, it appears that $\delta^{13} \mathrm{C}_{\mathrm{org}}$ values were affected by inputs of phytoplankton during endogenesis, and land $\mathrm{C}_{3}$ plants in exogenous intervals. The results [41] indicate that $\delta^{13} \mathrm{C}_{\text {org }}$ values were higher during cold-dry conditions, and lower values were present during warm-wet conditions. Similar conclusions have been inferred from other high resolution palaeoclimate records in the LGVF [15,16,22].

\section{Palaeoclimatic evolution}

Based on multi-proxy analyses of dry density, TOC contents, TN contents, $\delta^{13} \mathrm{C}_{\text {org }}$ ratios and sporopollen assemblages [42], the evolutional periods of palaeoclimate in the Erlongwan Maar Lake were divided into the following six stages since the last $14 \mathrm{ka} \mathrm{BP}$ (Figure 4).

This period is the typical transition period from the last glacial time to the Holocene (interglacial) with the outstanding features of frequent cold-warm alternations and strong climatic shocks. Increasing TOC and TN contents indicate an increasing mix of organic matter from terrigenous and autochthonous origins. The pollen data have signatures of trees and shrubby vegetation, developing a mixed coniferous broad leaved forest [42]. In addition, sharp declines of TOC contents between 12.2 and $11.4 \mathrm{ka} \mathrm{BP}$ indicate decreases in temperature. Higher $\delta^{13} \mathrm{C}_{\mathrm{org}}$ values and increased dry density data show poor climate conditions. Moreover, analysis of percentage pollen [42] and grain size [43] point to dry-cold climate conditions. The data also indicate the occurrence of YD events in this region, similar to the YD event in the GISP2 ice core [44]. Higher $\delta^{13} \mathrm{C}_{\text {org }}$ values of sediment records from Sihailongwan between 12.7 and $11.7 \mathrm{ka}$ BP also suggest YD-like cold event [23].

\subsection{Climatic transitional period (14-11.4 ka BP)}

After the end of this cold event, a new climate cycle began, characterized as the Holocene warm period. TOC content varied with high frequency and substantially tended to increase in both TOC and TN contents since the Holocene. This indicates that the climate was not balanced and rather had many cold-warm alternations. However, this alternation 


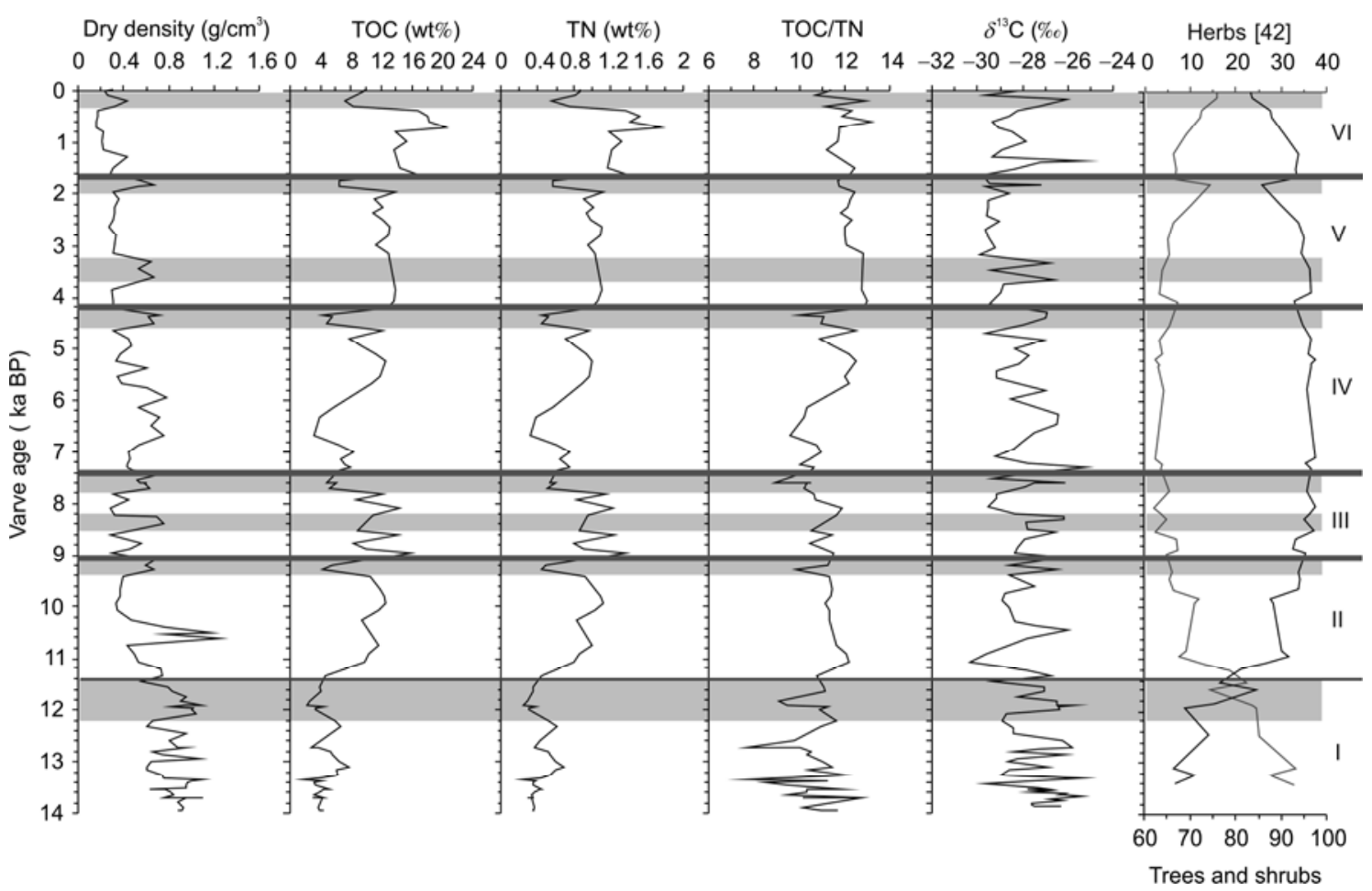

Figure 4 Climatic evolution as indicated by the multi-proxy analyses from the Erlongwan sediment record for the past 14 ka BP (horizontal gray bars represent cold events).

cycle was short lived.

According to multi-proxy records, climatic evolution since the Holocene can be divided into five stages (II-VI), and each climate stage began with smooth warming and ended with an abrupt cooling event.

\subsection{Warm-wet stage (11.4-9.05 ka BP)}

The climate was still in the high-frequency oscillatory condition after the YD. TOC contents, TN contents and TOC/ $\mathrm{TN}$ ratios increased. Dry density and herb pollen were also significantly reduced, which demonstrates a rapid warming at this time, and more terrestrial organic matter also was washed into the lake. Other evidence from grain size data [43] indicates that lake sediments were coarse. These features reflect a warm-wet climate and abundant precipitation in the Erlongwan region. Lower $\delta^{13} \mathrm{C}_{\mathrm{org}}$ values resulted from inputs of terrestrial $\mathrm{C}_{3}$ plants with more precipitation, which agrees well with interpretations of lower $\delta^{13} \mathrm{C}_{\text {org }}$ values from sediments in Xiaolongwan and peat in Jinchuan. It is suggested that $\delta^{13} \mathrm{C}_{\text {org }}$ values may have been indicators of humidity or precipitation in this study area. A cold event reappeared until $9.4 \mathrm{ka} \mathrm{BP}$, which marked the beginning of the next climate stage, after a continuity of approximately $350 \mathrm{a}$.

\subsection{Cold and warm fluctuating stage (9.05-7.4 ka BP)}

Pollen analysis showed that the elm, as the representative of the deciduous broad-leaved forest, dominated in this period.
In addition, TOC contents generally increased, and there was an overall reduction of dry density, indicating a warmer climate. However, two short cold events also appeared at 8.5-8.2 and 7.8-7.4 ka BP, accompanied by increases in dry density and decreases in TOC, TN contents and TOC/TN ratios. Finer grain sizes [43] indicating colder climate also was a response to the $8.2 \mathrm{ka} \mathrm{BP}$ event. It is noteworthy to mention that a cold event from 8.5 to $8.2 \mathrm{ka}$ BP may have been a response to a $8.2 \mathrm{ka} \mathrm{BP}$ global cold event which is not found in the sediment samples [23] from Sihailongwan or from peat [17] in Jinchuan. In addition, a new cold event was found within the 7.8 to $7.4 \mathrm{ka}$ BP interval, which should be investigated further.

\subsection{Smooth warming climate stage (7.4-4.2 ka BP)}

Climate became stable over a long period after the end of the $7.4 \mathrm{ka}$ BP cold event, and had a general warming trend. TOC/TN ratios increased slightly, corresponding with an increased input of terrestrial organic matter. The pollen assemblage illustrates that no major change of vegetation type occurred. It is inferred that an extreme cold event corresponded with an abrupt increase of dry density and decrease of TOC, TN content and TOC/TN ratios from 4.6 to $4.2 \mathrm{ka} \mathrm{BP}$.

\subsection{Climate optimum stage (4.2-1.67 ka BP)}

Pine pollen [42] increased significantly and reached its maximum within this profile, indicating that temperature 
clearly decreased in the Erlongwan region. However, rapid decreases in pine pollen reveals that temperatures increased gradually. Humidity was not significantly changed with respect to changes in temperature. Many herbaceous plants increased in abundance slowly, and they peaked near $1.9 \mathrm{ka}$ BP, which shows that humidity decreased slowly. Generally, the climate was cool and wet. Similar results were obtained in the sporo-pollen records from the Jinchuan peat [17]. The climate was optimum during this stage, but two cold events appeared in the 2-1.67 ka BP interval, with distinct increases in density and decreases in TOC and TN contents during 3.7-3.25 ka BP.

\subsection{Cool and drier stage (from $1.67 \mathrm{ka}$ BP to present)}

The sporo-pollen concentration decreased distinctly, and pine was the main vegetation during this stage [42], which indicates climatic features of overall cooling. TOC and TN contents reached the highest values at this stage, and declined rapidly until $0.3 \mathrm{ka} \mathrm{BP}$. In addition, TOC/TN ratios were similar as before, indicating that the source of organic matter did not change and had equal contribution between land plants and aquatic plants. The slightly higher $\delta^{13} \mathrm{C}_{\text {org }}$ values indicate a trend of drying climate. A cold event with $0.3-0.03 \mathrm{ka} \mathrm{BP}$ in this stage corresponds to the latest Little Ice Age, just as cold periods were ubiquitous in the 17th and 19th centuries [45]. Thus, it has been warming since 1920 $\mathrm{AD}$ in this stage, which indicates a new climate stage.

\section{Conclusions}

Lake sediments from Erlongwan Maar Lake provide a valuable material base for dating and identification of climatic development due to abundant organic matter and preservation of varves. We established the highest-resolution chronology series over the last $14 \mathrm{ka} \mathrm{BP}$ by combining varve counts with AMS ${ }^{14} \mathrm{C},{ }^{137} \mathrm{Cs}$ and ${ }^{210} \mathrm{~Pb}$ dating results from sediment analyses.

According to multi-proxy analysis of dry density, TOC content, TN content, TOC/TN ratios, $\delta^{13} \mathrm{C}_{\text {org }}$ ratio and sporopollen, the evolutional periods of palaeoclimate were identified as 6 climate stages within the last $14 \mathrm{ka}$ BP in Erlongwan Maar Lake. In particular, 7 cold events were identified as follows: 9.4-9.05, 8.5-8.2, 7.8-7.4, 4.6-4.2, 3.7-3.25, 2-1.67 and 0.3-0.03 ka BP. Compared with previous results [46], there are two improvements in the present contribution. One is that there were intervals for each event, rather than single time points. In addition, each interval was between 300 and 400 a, but not between 100 and 200 a. The other improvement is that a high-resolution time scale is closer to the actual conditions.

Each climate stage began with a smooth warming event and ended with an abrupt cooling event. In general, these climatic variation periods are neither equal nor symmetric, and display trends of cycle shortening and accelerated climate variability. These climate change features may be universal, and will provide new ideas to evaluate regional and global climatic evolution.

We thank Dr. Jens Mingram and Dr. Ute Frank from GeoForschungsZentrum Potsdam for making thin sections and providing samples. Prof. Han Jingtai, Dr. Chu Guoqiang, Dr. Liu Qiang and Dr. Liu Yuying are kindly acknowledged for their help with data analysis. We also thank anonymous reviews and the editor for their valuable comments, which greatly improved this manuscript and Dr. Patrick Rioual for correcting the English version of this manuscript. This work was supported by the National Natural Science Foundation of China (40802038) and the President Fund of GUCAS.

1 PAGES. Science Plan and Implementation Strategy. IGBP Report No. 57. Stockholm: IGBP Secretariat, 2009. 67

2 Wang Y J, Cheng H, Edwards R L, et al. A high-resolution absolute-dated Late Pleistocene monsoon record from Hulu Cave, China. Science, 2001, 294: 2345-2348

3 Dykoski C A, Edwards R L, Cheng H, et al. A high-resolution, absolutedated Holocene and deglacial Asian monsoon record from Dongge Cave, China. Earth Planet Sci Lett, 2005, 233: 71-86

4 Chen X, Yu G, Liu J. Simulation of abrupt climate change in eastern Asia during Younger Dryas (in Chinese). Quat Sci, 2004, 24: 654662

5 Ganopolski A, Rahmstorf S. Rapid changes of glacial climate simulated in a coupled climate model. Nature, 2001, 409: 153-159

6 Mao X, Jiang H C, Yang G F, et al. Preliminary study on spatial and temporal characteristics of palaeoclimate evolution in China during the last deglaciation (in Chinese). Quat Sci, 2011, 31: 57-65

7 Shen J, Liu X Q, Wang S M, et al. Palaeoclimatic changes in the Qinghai Lake area during the last 18000 years. Quat Int, 2005, 136: 131-140

8 Brauer A, Negendank J F W. The value of annually laminated lake sediments in palaeoenvironment reconstruction. Quat Int, 2002, 88: $1-3$

9 Rhodes T E, Gasse F, Lin R, et al. A late Pleistocene-Holocene lacustrine record from Lake Manas, Zunggar (northern Xinjiang, western China). Palaeogeogr Palaeoclimatol Palaeoecol, 1996, 120: 105-121

10 Lü X M, Zhu L P, Nishimura M, et al. A high-resolution environmental change record since $19 \mathrm{cal}$ ka BP in Pumoyum Co, southern Tibet. Chin Sci Bull, 2011, 56: 2931-2940

11 Brauer A, Endres C, Günter C, et al. High resolution sediment and vegetation responses to Younger Dryas climate change in varved lake sediments from Meerfelder Maar, Germany. Quat Sci Res, 1999, 18: 321-329

12 Chu G Q, Liu J Q, Liu D S. Discrimination of two kinds of sedimentary laminae in maar lakes of China. Chin Sci Bull, 2000, 45: 22922295

13 Schettler G, Liu Q, Mingram J, et al. Palaeovariations in the East-Asian monsoon regime geochemically recorded in varved sediments of Lake Sihailongwan (Northeast China, Jilin province). Part 1: Hydrological conditions and dust flux. J Paleolimnol, 2006, 35: 239-270

14 Frank U. Rock magnetic studies on sediments from Erlongwan Maar Lake, Long Gang Volcanic Field, Jilin province, NE China. Geophys J Int, 2007, 168: 13-26

15 Chu G Q, Sun Q, Wang X H, et al. A 1600 year multiproxy record of paleoclimatic change from varved sediments in Lake Xiaolongwan, northeastern China. J Geophys Res, 2009, 114: D22108

16 Hong Y T, Wang Z G, Jiang H B, et al. A 6000-year record of changes in drought and precipitation in northeastern China based on a $\delta^{13} \mathrm{C}$ time series from peat cellulose. Earth Planet Sci Lett, 2001, 185: 111-119

17 Jiang W Y, Leroy S A G, Ogle N, et al. Natural and anthropogenic 
forest fires recorded in the Holocene pollen record from a Jinchuan peat bog, northeastern China. Palaeogeogr Palaeoclimatol Palaeoecol, 2008, 261: 47-57

18 Yamamoto S, Kawamura K, Seki O, et al. Environmental influences over the last $16 \mathrm{ka}$ on compound-specific $\delta^{13} \mathrm{C}$ variations of leaf wax $\mathrm{n}$-alkanes in the Hani peat deposit from northeast China. Chem Geol, 2010, 277: 261-268

19 Zhou W J, Zheng Y H, Meyers P A, et al. Postglacial climate-change record in biomarker lipid compositions of the Hani peat sequence, Northeastern China. Earth Planet Sci Lett, 2010, 294: 37-46

20 Seki O, Meyers P A, Kawamura K, et al. Hydrogen isotopic ratios of plant wax $n$-alkanes in a peat bog deposited in northeast China during the last 16 kyr. Org Geochem, 2009, 40: 671-677

21 Stebich M, Mingram J, Han J T, et al. Late Pleistocene spread of (cool-) temperate forests in Northeast China and climate changes synchronous with the North Atlantic region. Global Planet Change, 2009, 65: 56-70

22 Parplies J, Lücke A, Vos H, et al. Late glacial environment and climate development in northeastern China derived from geochemical and isotopic investigations of the varved sediment record from Lake Sihailongwan (Jilin Province). J Paleolimnol, 2008, 40: 471-487

23 Liu Q, Liu J Q, Chen X Y, et al. Stable carbon isotope record of bulk organic matter from the Sihailongwan maar lake, northeast China during the past $18.5 \mathrm{ka}$ (in Chinese). Quat Sci, 2005, 25: 711-721

24 Hong Y T, Liu D S, Jiang H B, et al. Evidence for solar forcing of climate variation from $\delta^{18} \mathrm{O}$ of peat cellulose. Sci China Ser D-Earth Sci, 2000, 43: 217-224

25 You H T, Liu J Q, Liu Q, et al. Study of the varve record from Erlongwan maar lake, NE China, over the last 13 ka BP. Chin Sci Bull, 2008, 53: 262-266

26 You H T, Liu Q, Liu J Q, et al. Research methodology preliminary results for varved lacustrine sediments of the Sihailongwan maar lake (in Chinese). Earth Environ, 2006, 34: 71-76

27 You H T, Liu Q, Liu J Q, et al. A comparative study on model sedimentation rates with varve dating, ${ }^{137} \mathrm{Cs}$ and ${ }^{210} \mathrm{~Pb}$ dating in Erlongwan maar lake, NE China (in Chinese). J Jilin Univ, 2007, 37: 59-64

28 Zolitschka B, Negendank J F W. Sedimentology, dating and paleoclimatic interpretation of a 76.3 ka record from Lago Grande di Monticchio, southern Italy. Quat Sci Res, 1996, 15: 101-112

29 Liu J Q, Lü H Y, Negendank J F W, et al. Periodicity of Holocene climate variations in the Huguangyan maar lake. Chin Sci Bull, 2000, 45: 1712-1717

30 Shen J, Yang L Y, Yang X D, et al. Lacustrine records in the catchment of Erhai with respect to climatic change and human activities in the lake, Yunnan Province, over the Holocene (in Chinese). Sci Chi- na Ser D-Earth Sci, 2004, 34: 130-138

31 Nakai N. Carbon isotopic variation and paleoclimate of sediments from Lake Biwa. Proc Jpn Acad, 1972, 48: 516-521

32 Wang S M, Ji L. Hulun Lake: Ancient Lake Study (in Chinese). Beijing: Science Press, 1995. 70-86

33 Meyers P A, Lallier V E. Lacustrine sedimentary organic matter records of Late Quaternary paleoclimates. J Paleolimnol, 1999, 21: 345-372

34 Brahney J, Clague J J, Menounos B, et al. Timing and cause of water level fluctuations in Kluane Lake, Yukon Territory, over the past 5000 years. Quat Res, 2008, 70: 213-227

$35 \mathrm{Wu}$ J, Shen J. Paleoenviromental and paleoclimatic changes in Lake Xingkai inferred from stable carbon and nitrogen isotopes of bulk organic matter since $28 \mathrm{ka}$ (in Chinese). Acta Sedimentol Sin, 2010, 28: $365-372$

36 Chen J A, Wan G J, Wang F S, et al. Environment records of carbon in recent lake sediments. Sci China Ser D-Earth Sci, 2002, 45: 875-884

$37 \mathrm{Ma} \mathrm{L}, \mathrm{Wu} \mathrm{J}$ L. Environmental significance from organic carbon and its isotopes in Angulinao lake sediment (in Chinese). J Nat Resour, 2009, 24: 1099-1104

38 Wu J L, Wang S M. Climate versus changes in $\delta^{13} \mathrm{C}$ values of organic matter in lake sediments (in Chinese). Mar Geol Quat Geol, 1996, 16: 105-109

39 O'Leary M H. Carbon isotopes in photosynthesis. BioScience, 1988, 38: $328-336$

40 Mingram J, Allen J, Bruchmann C, et al. Maar and crater lakes of the Long Gang Volcanic Field (NE China)-overview, laminated sediments, and vegetation history of the last 900 years. Quatern Int, 2004, 123-125: 135-147

41 Wang G A, Han J M, Zhou L P. The annual average temperature in northern China (in Chinese). Geol China, 2002, 29: 55-57

42 Liu Y Y. Vegetation and environment history of Erlongwan maar lake since the late Pleistocene (in Chinese). Dissertation for the Doctoral Degree. Changchun: Jilin University, 2009. 72-76

43 Wei Q, Han J T, Li D. Grain size distribution patterns and paleoenvironmental implications of the sedimentary sequence in the Erlongwan maar lake, Northeastern China for the last $32 \mathrm{ka}$ (in Chinese). Quat Sci, 2008, 28: 957-958

44 Stuiver M, Grootes P M, Braziunas T F. The GISP2 $\delta^{18} \mathrm{O}$ Climate record of past 16500 years and the role of the Sun, ocean, and volcanoes. Quat Res, 1995, 44: 254-341

45 Wang S W. Studies on climate of the little ice age (in Chinese). Quat Sci, 1995, 15: 202-212

46 Bond G, Showers W, Cheseby M, et al. A pervasive millennial-scale cycle in North Atlantic Holocene and glacial climates. Science, 1997, 278: $1257-1266$

Open Access This article is distributed under the terms of the Creative Commons Attribution License which permits any use, distribution, and reproduction in any medium, provided the original author(s) and source are credited. 